\title{
PERBEDAAN RENCANA TANGGAP DARURAT GEMPA BUMI PADA SEKOLAH DASAR DAERAH PESISIR DAN DAERAH PERKOTAAN DI MALANG
}

\author{
Mia Andinawati ${ }^{1)}$, Noorhamdani ${ }^{2}$, Yati Sri Hayati ${ }^{3)}$ \\ 1),3) Program Studi Magister Keperawatan Universitas Brawijaya \\ 2) Fakultas Kedokteran Universitas Brawijaya \\ E-mail: mia.andinawati@gmail.com
}

\begin{abstract}
Indonesia is an earthquake-prone country. The most victim caused by earthquake were school age children. Malang coastal area has 3 times higher earthquake prone than urban area, but urban area has bigger risk. of victim and loss. This study aimed to determine differences in earthquake emergency response plans. This research uses observational descriptive with cross sectional design. Population is all principal of elementary school in Malang including coastal and urban area, and sample 34 principal of elementary school in urban area and 34 principal of elementary school in coastal area with purposive sampling. The data were analysed usin Mann-whitney test and significance test using SPSS 16 for windows. The results show that $p$ value (sig) $>0,05$ and 1,00 >0,05 wich mean no differences in earthquake emergency response plans. However in coastal area has higher score than urban area. Coastal area has score 10,4 and urban area has score 2,3. Monitoring, reviewing, and updating in earthquake emergency response plans and the development of new initiatives should be built on every school.
\end{abstract}

Keywords : Earthquakes; elementary school of coastal area; elementary school of urban area.

\begin{abstract}
ABSTRAK
Indonesia merupakan negara rawan bencana alam, salah satunya gempa bumi. Korban jiwa paling banyak akibat gempa bumi adalah anak usia sekolah. Daerah pesisir Kabupaten Malang memiliki tingkat rawan bencana gempa bumi 3 kali lebih banyak daripada Kota Malang, akan tetapi risiko kerugian dan korban jiwa akibat gempa bumi lebih besar di Kota Malang. Tujuan penelitian ini adalah untuk mengetahui perbedaan rencana tanggap darurat gempa bumi pada sekolah dasar daerah pesisir dan daerah perkotaan. Metode penelitian menggunakan deskriptif observasional dengan rancangan cross sectional. Populasi dalam
\end{abstract}


penelitian ini adalah kepala sekolah dari seluruh SD yang berada di Kota Malang dan di pesisir Kabupaten. Jumlah sampel masing-masing sebanyak 34 kepala sekolah dari sekolah dasar yang berlokasi di perkotaan Kota Malang dan di daerah pesisir selatan Kabupaten Malang. Teknik sampling menggunakan purposive sampling. Analisa data menggunakan uji Mann-Whitney dengan selang kepercayaan 95\% dan uji signifikansi menggunakan SPSS 16 for windows. Hasil penelitian menunjukkan $\mathrm{p}$ value (sig) $>0,05$ yaitu 1,00 >0,05 yang bermakna tidak terdapat perbedaan yang signifikan dalam rencana tanggap darurat gempa bumi pada sekolah dasar daerah pesisir dan daerah perkotaan. Akan tetapi dari skor ratarata yang dicapai, Sekolah Dasar daerah pesisir memiliki skor rencana tanggap darurat yang lebih tinggi yaitu sebesar 10,4 daripada daerah perkotaan sebesar 2,3. Diharapkan sekolahsekolah membuat skema rencana tanggap darurat gempa bumi sehingga dapat meminimalisir jumlah korban dan kerugian akibat bencana gempa bumi.

Kata Kunci : Gempa Bumi; Sekolah Dasar Daerah Pesisir; Sekolah Dasar Daerah Perkotaan

\section{PENDAHULUAN}

Penduduk Indonesia selama 2014, terdapat total sebanyak 157 juta jiwa terpajan sedang sampai tinggi dari adanya gempa di Indonesia (BNPB, 2014). Gempa terbaru yang tercatat terjadi di Lebak Provinsi Banten pada 24 Januari 2018. Pada gempa berkekuatan 6,1 skala richter ini tidak menimbulkan korban jiwa, tetapi menimbulkan banyak kerusakan seperti rumah, puskesmas dan juga sekolah yaitu robohnya gedung SMA Cahaya Madani Banten Boarding School (CMBBS) Pandeglang (Dalimunthe, 2018). Data Bank Dunia (BNPB, 2014) mengatakan Indonesia termasuk dalam 4 besar negara di dunia dengan jumlah sekolah yang banyak. Sejumlah sekolah berada di daerah dengan risiko gempa tinggi. Sebagai contoh untuk sekolah SD dari total 144.507, sebanyak 109.401 terletak di provinsi Jawa Timur dengan risiko terjadi gempa yang tinggi.

Menurut Iskandar (2010) Sebagian besar korban dari bencana tersebut adalah anak usia sekolah dan lansia. Anak-anak kurang mengetahui mengenai bencana tersebut dan tindakan yang seharusnya dilakukan. Terkhusus bencana gempa bumi, korban yang meninggal rata-rata diakibatkan kejatuhan reruntuhan, yaitu terbanyak wanita dan anak - anak (Siwaku, 2015). Efek dari bencana itu akan menjadi parah apabila terjadi ketika belajar mengajar sedang berlangsung, misalnya ketika terjadi gempa bumi kemudian bangunan dan benda sekitarnya menjadi roboh, dan menimpa atau menimbun murid-murid, guru maupun yang lainnya. Oleh sebab itu, dibutuhkan suatu rencana tanggap darurat pada tiap 
sekolah untuk menjamin keamanan dan keselamatan seluruh warga sekolah dari ancaman bencana setiap saat (Kemendikbud, 2015).

Pada tanggal 31 Maret 2010, Menteri Pendidikan Nasional mengeluarkan Surat Edaran Mendiknas Nomor 70a/MPN/SE/2010 yang ditujukan kepada Gubernur, Walikota/Bupati di seluruh Indonesia yang berisi peraturan untuk melaksanakan upaya pengurangan risiko bencana di lingkup sekolah. Upaya tersebut akan tercapai dengan suatu kebijakan mengenai rencana tanggap darurat masing-masing sekolah meliputi perencanaan evakuasi yang matang, pelatihan simulasi bencana dan pertolongan pertama, pembentukan gugus siaga bencana serta pembuatan protap evakuasi.

Berdasarkan survei melalui studi pendahuluan yang peneliti lakukan meliputi kebijakan mengenai rencana tanggap darurat masing-masing sekolah meliputi perencanaan evakuasi yang matang, pelatihan simulasi bencana dan pertolongan pertama, pembentukan gugus siaga bencana serta pembuatan protap evakuasi, tidak semua SD di Kabupaten/Kota malang yang mengetahui atau melakukan upaya rencana tanggap darurat di sekolah. Studi Pendahuluan yang dilakukan di SDN Wonorejo IV Kecamatan Bantur, Sekolah dengan jumlah siswa 141 dengan guru dan staf yang berjumlah 12 orang, belum pernah ada sosialisasi, materi kurikulum ataupun kegiatan yang berhubungan dengan persiapan penanganan bencana gempa bumi. Berdasarkan lokasi Malang bagian selatan merupakan daerah rawan gempa (Irsyam dkk, 2017). Sementara SDN Madyopuro 5 yang berada di Kota Malang mengatakan sudah memasukkan kurikulum kebencanaan terhadap siswasiswi kelas 4,5 dan 6. Akan tetapi belum pernah melakukan pelatihan tentang bencana ataupun pembuatan suatu protap rencana tanggap darurat bencana.

Berdasarkan uraian diatas, peneliti bermaksud melakukan penelitian mengenai perbedaan rencana tanggap darurat gempa bumi pada sekolah dasar daerah pesisir dan daerah perkotaan.

\section{METODE PENELITIAN}

Penelitian ini menggunakan desain deskriptif observasional dengan rancangan cross sectional. Populasi dalam penelitian ini adalah kepala sekolah dari seluruh SD yang berada di Kota Malang sebanyak 274 sekolah, dan kepala sekolah dari seluruh SD yang berada di pesisir 
Kabupaten Malang sebanyak 74 sekolah. Jumlah sampel sebanyak 34 kepala sekolah dari Wilayah Kota Malang yang diambil dari SD di Kecamatan Kedungkandang, Sukun dan Klojen, dan 34 kepala sekolah dari Wilayah Kabupaten Malang yang diambil dari SD yang berlokasi di Kecamatan Bantur, Donomulyo dan Sumbermanjingwetan. Teknik sampling menggunakan purposive sampling. Waktu penelitian ini dilaksanakan pada 10 Januari - 15 Februari 2019.
Instrument yang digunakan pada penelitian ini adalah kuesioner multiple choice question (MCQ) tentang penilaian rencana tanggap darurat sekolah terhadap bencana gempa bumi, yang diambil dari LIPI Pusat Geoteknologi (2013) dan kuesioner klasifikasi daerah perkotaan/ desa dari Badan Pusat Statistik (2010). Analisis data bivariat menggunakan uji Mann-Whitney, serta aplikasi program komputer SPSS 16.00 for windows. Penelitian ini dilakukan berdasarkan etika penelitian yaitu informed consent, beneficience, otonomy dan veracity.

\section{HASIL}

Tabel 1. Karakteristik umum Sekolah Dasar daerah pesisir Kabupaten dan Sekolah Dasar perkotaan Kota Malang

\begin{tabular}{|c|c|c|c|}
\hline \multirow[t]{2}{*}{ Variabel } & \multirow[t]{2}{*}{ Kategori } & \multicolumn{2}{|c|}{$\begin{array}{c}\text { Lokasi Sekolah Dasar } \\
\qquad(\%)\end{array}$} \\
\hline & & Pesisir & Perkotaan \\
\hline \multirow[t]{2}{*}{ Jarak sekolah dari pantai } & Dekat (kurang dari 500 meter) & 0.00 & 0.00 \\
\hline & Jauh (lebih dari 2000 meter) & 100.00 & 100,00 \\
\hline \multirow{2}{*}{$\begin{array}{l}\text { Jarak sekolah dari pantai ( dari } \\
\text { ketinggian air laut) }\end{array}$} & $\operatorname{Rendah}(<5$ meter dpl $)$ & 97.06 & 0.00 \\
\hline & Tinggi(>10 meter $\mathrm{dpl})$ & 2.94 & 100,00 \\
\hline \multirow[t]{2}{*}{ Jenis dinding bangunan terbanyak } & Beton/bata & 92.2 & 76.4 \\
\hline & Kayu/ papan & 11.78 & 23.4 \\
\hline \multirow[t]{2}{*}{ Jenis bangunan } & Bertingkat & 5.88 & 91.16 \\
\hline & Tidak Bertingkat & 94.12 & 8.82 \\
\hline \multirow[t]{2}{*}{ Kondisi bangunan sekolah } & $\begin{array}{l}\text { Bagian bangunan yang panjang, } \\
\text { sejajar dengan pantai }\end{array}$ & 80.34 & 88.22 \\
\hline & $\begin{array}{l}\text { Bagian bangunan yang panjang, } \\
\text { tegak lurus dengan garis pantai }\end{array}$ & 16.64 & 11.76 \\
\hline Bangunan sekolah mengikuti standar & $\mathrm{Ya}$ & 8.82 & 41.16 \\
\hline bangunan tahan gempa & Tidak & 91.16 & 58.8 \\
\hline Bangunan sekolah mengikuti standar & $\mathrm{Ya}$ & 8.82 & 5.88 \\
\hline $\begin{array}{l}\text { bangunan yang memperhitungkan } \\
\text { pengaruh beban tsunami }\end{array}$ & Tidak & 91.16 & 94.1 \\
\hline
\end{tabular}


Berdasarkan Tabel 1 seluruh sekolah dasar berjarak jauh dari pantai melebihi 2000 meter. Sebagian besar dinding sekolah dasar pesisir dan perkotaan berbahan beton/bata hanya sebagian kecil berbahan kayu/papan. Pada daerah pesisir hanya terdapat $5.88 \%$ bangunan sekolah bertingkat sedang kan persentase sekolah bertingkat lebih banyak pada daerah perkotaan yaitu sebesar $91.16 \%$. Sebagian kecil dari Sekolah Dasar pesisir yang telah mengikuti standar bangunan tahan gempa sebesar $8.82 \%$ sedangkan pada daerah perkotaan standar bangunan tahan gempa sebesar lebih besar yaitu $41.16 \%$. Standar bangunan yang memperhitungkan pengaruh beban tsunami hanya dimiliki sebagaian Sekolah Dasar pesisir dan perkotaan yaitu sebesar $14.70 \%$.

Berdasarkan Tabel 2 didapatkan hasil skor rencana tanggap darurat pada SD daerah pesisir lebih tinggi yaitu mean 10,4 dibandingkan SD daerah perkotaan yaitu mean sebesar 2,3.

Tabel 2. Skor Rencana Tanggap Darurat Gempa Bumi SD Daerah Pesisir dan SD Daerah Perkotaan

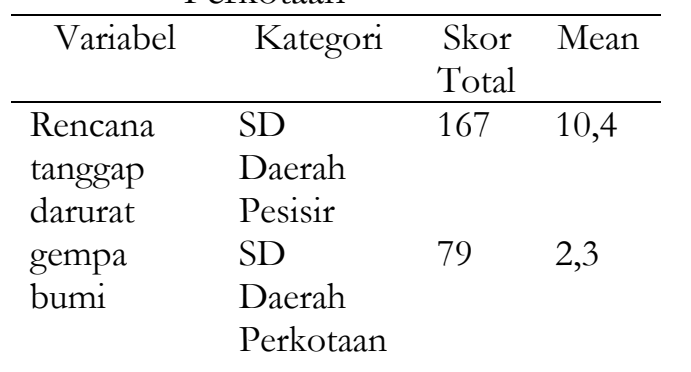

Berdasarkan Tabel 3, hasil uji MannWhitney menghasilkan nilai p-value (sig) $>0,05$ yaitu $1,00>0,05$ sehingga dikatakan bahwa tidak terdapat perbedaan rencana tanggap darurat gempa bumi pada Sekolah Dasar daerah pesisir dan daerah perkotaan.

Tabel 3. Hasil Perhitungan Uji Mann-Whitney

\begin{tabular}{lllll}
\hline & Mann-Whitney U & $\mathrm{Z}$ & Asymp. Sig. (2-tailed) & Keterangan \\
Rencana & 578,000 &, 000 & 1,000 & $\begin{array}{l}\text { Tidak didapat perbedaan } \\
\text { yang bermakna }\end{array}$ \\
$\begin{array}{l}\text { tanggap } \\
\text { darurat }\end{array}$ & & & & \\
gempa & & & \\
bumi & & & & \\
\hline
\end{tabular}


PEMBAHASAN

Rencana Tanggap Darurat Gempa Bumi Pada Sekolah Dasar Daerah Pesisir

Berdasarkan hasil penelitian yang tertuang dalam Tabel 2 didapatkan sekolah dasar pada daerah pesisir memiliki skor total sebanyak 167 atau mean 10,4. Menurut kuesioner, nilai mean dibawah 15 termasuk kategori rendah. Hal ini berarti rencana tanggap darurat gempa bumi pada sekolah dasar di daerah pesisir Kabupaten Malang termasuk dalam kategori rendah. Berdasarkan data tersebut, SD di Kabupaten Malang sebagian besar belum memiliki skema rencana tanggap darurat untuk mengantisipasi terjadinya bencana. Dari hasil kuesioner juga dapat disimpulkan kalau sekolah dasar belum mendapat arahan mengenai konsep tanggap bencana maupun pembuatan gugus siaga bencana.

Menurut RPJMD kabupaten Malang (2016) hampir keseluruhan wilayah Kabupaten Malang dibentuk dari hasil gunung api kwarter muda sebesar 44,25 $\%$. Wilayah Potensi Bencana Alam Gempa bumi, meliputi Kecamatan Dampit, Kecamatan Gedangan, Kecamatan Ampelgading Kecamatan Tirtoyudo dan Kecamatan
Sumbermanjing Wetan. Potensi gempa bumi di wilayah selatan Kabupaten malang karena daerah ini merupakan jalur gempa zona subduksi lempeng indoausralia di selatan jawa (Maulana, 2015). Frekuensi gempa di wilayah pesisir Kabupaten Malang terjadi 5 kali gempa yang signifikan dan merusak dengan pusat gempa berada diilepas pantai selatan Kabupaten Malang (Setiyono dkk, 2019).

Kebijakan tanggap darurat gempa bumi dapat dilakukan di sekolah dasar dilakukan dengan pembuatan rencana evakuasi yang matang, pelatihan simulasi bencana dan pertolongan pertama, pembentukan gugus siaga bencana serta pembuatan protap evakuasi (Triyono dkk, 2013). Pada daerah pesisir, protap tersebut dilakukan sejalan dengan protab tanggap darurat tsunami.

\section{Rencana Tanggap Darurat Gempa Bumi Pada Sekolah Dasar Daerah Perkotaan}

Berdasarkan hasil penelitian yang tertuang dalam tabel 2 didapatkan sekolah dasar pada daerah perkotaan memiliki skor total sebanyak 79 atau mean 2,3. Menurut kuesioner, nilai mean dibawah 15 termasuk kategori rendah. Hal ini berarti rencana tanggap darurat gempa bumi 
pada sekolah dasar di daerah Kota Malang termasuk dalam kategori rendah. Berdasarkan data tersebut, SD di Kota Malang sebagian besar belum memiliki skema rencana tanggap darurat untuk mengantisipasi terjadinya bencana. Dari hasil kuesioner juga dapat disimpulkan kalau sekolah dasar belum mendapat arahan mengenai konsep tanggap bencana maupun pembuatan gugus siaga bencana.

Frekuensi gempa yang terjadi di Di Kota Malang dalam 5 tahun terakhir terjadi 2 kali gempa yang signifikan dan merusak, (Setiyono dkk, 2019). Kondisi bangunan sekolah berdasarkan tabel 1 sebagian besar dinding sekolah dasar perkotaan berbahan beton/bata hanya sebagian kecil berbahan kayu/papan, dan memiliki standar bangunan tahan gempa sebesar $41.16 \%$. berdasarkan data tersebut pada daerah perkotaan akan sangat berbahaya jika terjadi gempa bumi karena sebagian besar bangunan bertingkat dan juga lingkungan sekitar yang padat. Hal ini sejalan dengan Setyowati (2019) bahwa gempa akan lebih berbahaya jika terjadi di lingkungan yang padat penduduk seperti daerah perkotaan. Alur kerusakan yang diakibatkan oleh gempa bumi yaitu energy guncangan dari pusat gempa dikeluarkan ke permukaan bumi sesuai dengan kedalaman pusatnya. Guncangan tersebut akan mengakibatkan kerusakan sekitar permukaan bumi dan menghancurkan bangunanbangunan yang ada diatas permukaan, dan selanjutnya membunuh dan melukai orang-orang yang berada didalaam bangunan tesebut. Guncangan tersebut nantinya akan menyebabkan tanah longsor, melelehnya endapan air, runtuhnya bebatuan dan masalah-masalah daratan yang lain, yang dapat merusak tempat-tempat tinggal warga disekitarnya. Guncangan tersebut nantinya akan mengakibatkan bencana sekunder dilingkungan tmpaat tinggal warga, berupa kebakaran, masalah kecelakaan dalam industri dan juga sistem transportasi. Selain itu dapat menimbulkan banjir bandang akibat jebolnya bendungan dan tanggul penahan banjir. Gempa bumi akan muncul secara tiba-tiba yang tidak dapat diprediksi dengan tepat sebelumnya, sehingga upaya peringatan dini sulit dilakukan. Belum ada teknologi yang dapat meramalkan munculnya gempa bumi secara tepat dalam waktu dekat dan lokasi pusat gempanya. Pada dasarnya yang berbahaya dari gempa bumi adalah runtuhnya bangunan-bangunan yang lemah terhadap guncangan sehingga dapat menimbulkan korban jiwa dan kerugian material. 
Bangunan tersebut biasanya dibangun tanpa perhitungan material yang baik, pemilihan lokasi yang kurang tepat, terlebih lagi jika bangunan tersebut adalah fasilitas umum termasuk rumah sakit dan gedung sekolah makan akan sangat membahayakan orang-orang yang berkepentingan didalamnya. (Setyowati, 2019).

Pusat Studi Gempa Nasional (PuSGeN) pada tahun 2018 melakukan overlay peta bahaya goncangan percepatan puncak dibatuan dasar (SB) untuk persentase 10 persen pada 50 tahun, maka didapatlkan bahwa sejumlah 216.816 .932 (77 persen) penduduk di Indonesia terpapar bahaya gempa lebih dari 0.1 g. Dari 216 juta jiwa tersebut, 4 juta (1.5 persen) diantaranya tinggal pada jarak $1 \mathrm{Km}$ dari sesar. Sebagai catatan, gempa bumi sudah dapat sangat merusak pada percepatan goncangan $0.1 \mathrm{~g}$ atau setara dengan intensitas VI Skala Mercalli atau Modifed Mercally Intensity/MMI (Pusgen, 2018).

\section{Perbedaan Rencana Tanggap Darurat Gempa Bumi Pada Sekolah Dasar Daerah Pesisir dan Daerah Perkotaan}

Berdasarkan Tabel 3, hasil uji MannWhitney menghasilkan nilai $\mathrm{p}$ value (sig) $>0,05$ yaitu $1,00>0,05$ sehingga dikatakan bahwa tidak terdapat perbedaan rencana tanggap darurat gempa bumi pada Sekolah Dasar daerah pesisir dan daerah perkotaan, meskipun begitu nilai skor rencana tanggap darurat gempa bumi sekolah dasar daerah pesisir lebih tinggi yaitu dengan mean 10,4 daripada sekolah dasar daerah perkotaan dengan nilai mean sebesar 2,3. Kota Malang dan Kabupaten Malang yang merupakan daerah yang masih ada didalam wilayah pulau jawa dan juga bukan daerah terpencil masih belum memiliki pengetahuan dan sikap yang memadai terkait kesiagaan terhadap bencana (Setiyono dkk, 2018). Terlebih lagi Kabupaten Malang yang memiliki risiko tinggi rawan bencana gempa bumi.

Rencana tanggap darurat bencana merupakan kegiatan yang sangat penting dalam penanggulangan bencana, karena kegiatan ini merupakan kegiatan sebelum terjadinya bencana yang dimaksudkan untuk mengantisipasi agar dampak yang ditimbulkandapat dikurangi. Di wilayah pesisir dapat dilakukan secara structural maupun non structural. Secara structural dapat dengan melakukan upaya teknis baik secara alami maupun buatan seperti pemuatan breakwater dan penanaman mangrove untuk mitigasi tsunami, pembangunan tanggul, kanal diversi, pintu air pengendali banjir, normalisasi 
sungai, dan sistem polder pada daerah rawan banjir, groin pada wilayah pesisir yang tererosi, dan pembuatan struktur tahan bencana. Sedangkan mitigasi secara non struktural adalah upaya non teknis yang menyangkut penyesuaian dan pengaturan tentang kegiatan manusia agar sejalan dan sesuai dengan upaya mitigasi structural atau upaya lainnya.

Usher dan Meyner meneliti tentang tingkat pengetahuan mahasiswa ilmu keperawatan di Australia dengan melibatkan 39 intitusi pendidikan tinggi. Hasil penelitiannya menyimpulkan bahwa hampir seluruh responden tidak memiliki pengetahuan yang adekuat tentang kesiapan bencana karena 63\% dari total responden belum pernah menerima pendidikan terkait bencana di universitas. Tanaka (2005) tentang kesiapan dan mitigasi terkait gempa bumi terhadap 361 responden di Fukui dan 190 responden di San Francisco menyimpulkan bahwa komunitas yang berada di lingkungan rawan bencana cenderung mampu menerapkan perilaku siap siaga dalam kehidupan sehari-hari.

Berdasarkan Undang-Undang Nomor 24 Tahun 2007 tentang penanggulangan bencana dan Peraturan Pemerintah Nomor 21 Tahun 2008 tentang
Penyelenggaraan Penanggulangan Bencana, Kementrian Pendidikan Nasional telah menyusun strategi pengurangan risiko bencana di Sekolah yang dilengkapi dengan modul bahan ajar dan pelatihan pengintegrasian pengurangan risiko bencana. Melalui Surat Edaran Menteri Pendidikan Nasional Nomor 70a/MPN/SE/2010, Menteri Pendidikan Nasional menghimbau kepada seluruh kepala daerah di Indonesia untuk melaksanakan strategi pengarusutamaan pengurangan risiko bencana di sekolah. Pelaksanaan strategi pengarusutamaan pengurangan risiko bencana di sekolah dilakukan baik secara struktural maupun non-struktural gunamewujudkan budaya kesiapsiagaan dan keselamatan terhadap bencana di sekolah (Triyono dkk, 2013).

Kemendikbud dan BNPB saat ini melakukan terobosan menggunakan teknologi pemetaan dengan integrasi Data Pokok Pendidikan (DAPODIK) dan peta ancaman bencana di seluruh Indonesia (BNPB, 2017). Dengan hal itu, diharapkan setiap orang bisa mengetahui bahaya bencana apa saja yang mengancam Sekolah dimanapun di Indonesia. Informasi yang ada akan dikembangkan lagi dimana kelak seluruh sekolah akan dikaji keamanan bangunan 
sekolah dan fasilitasnya terhadap ancaman bencana, sehingga setiap orang dapat mengetahui dimana kerentanan yang ada serta rekomendasi yang dapat dilakukan di tiap sekolahuntuk memastikan sekolah tersebut aman dari bencana.

\section{KESIMPULAN}

Sekolah dasar di daerah pesisir Kabupaten Malang maupun di darah perkotaan Kota Malang tidak memiliki perbedaan rencana tanggap darurat. Hal ini dapat dilihat dari rendahnya skor yang didapat, meski hasilnya total skor lebih tinggi pada daerah pesisir.

\section{SARAN}

Berdasarkan hasil penelitian yang diperoleh diharapkan semua sekolah meningkatkan rencana tanggap darurat gempa bumi sehingga dapat meminimalisir jumlah korban dan kerugian akibat bencana gempa bumi. Kebijakan tanggap darurat gempa bumi dapat dilakukan dengan pembuatan rencana evakuasi yang matang, pelatihan simulasi bencana dan pertolongan pertama, pembentukan gugus siaga bencana serta pembuatan protap evakuasi.

\section{REFERENSI}

Badan Nasional Penanggulangan Bencana (BNPB). (2014). Data Bencana Nasional. Jakarta

Badan Nasional Penanggulangan Bencana (BNPB). (2017). Buku Pedoman Latiban Kesiapsiagaan Nasional: Membangun Kesadaran, Kewaspadaan, dan Ksiapsiagaan dalam Menghadapi Bencana. Jakarta

Dalimunthe, I. (2018). Gempa Bumi Guncang Pandeglang Banten. CNN Indonesia. 5 April 2018.

Irsyam, M., Hendriyawan, M. Asrurifak, Requel Mikail, Arif Sabaruddin, Lutfi Faisal dkk. (2017). Katalog Pusat studi gempa Bumi Nasional. Bandung: Pusgen.

Iskandar. (2010). Situasi Kebencanaan Aceh Terkini. Makalah disampaikan pada Workshop Penggalangan Peer Group Peneliti kebencanaan TDMRC. Unsyiah.

Kemendikbud. (2015). Roadmap Sekolah / Madrasah Aman. Jakarta: Kemendikbud \& UNICEF.

Pusat Studi Gempa Nasional (Pusgen). (2018). Peta Sumber dan Bahaya Gempa Indonesia Tabun 2018. Jakarta: Pusat Litbang Perumahan dan Pemukiman, Badan Penelitian dan Pengembangan, Kementrian Pekerjaan Umum dan Perumahan Rakyat.

Rencana Pembangunan Jangka Menengah Daerah (RPJMD) Kota Malang tahun 2018 - 2023. (2018). Malang: Pemerintah Kota Malang.

Setiyono, U., Gunawan, I., Priyobudi, Yatimantoro, T., Imananta, R.T., Ramdha, M., Dkk. Katalog Gempa Bumi Signifikan Dan Merusak. 1821 2018. Jakarta. Pusat Gempabumi dan Tsunami Kedeputian Bidang Geofisika Badan Meteorologi Klimatologi dan Geofisika. 
Setyowati, D.L. (2019). Pendidikan Kebencanaan. Semarang. Universitas Negeri Semarang

Shiwaku, K. (2015). Comparative study on teacher training for school disaster management in Armenia and Japan. Disaster Prevention and Management $23 \quad$ (2) 197-211 DOI 10.1108/DPM-12-2012-0144

Sikumbang, E. (2016). Evaluasi Kinerja Badan Penanggulangan Bencana Daerah Dari Aspek. Kesiapsiagaan Masyarakat Terhadap Penanggulangan Bencana (Studi
Kasus Kota Padang). Masters thesis, Universitas Andalas.

Tanaka, K. (2005). The Impact of Disaster on Public Preparation and Mitigation for earthquakes : a Cross Country Comparison between Fukui, Japan and the San Fransisco Bay Area, California, USA. Applied Geography Journal Volume 25 issue 3 pg 201- 225

Triyono, Putri, Koswara dan Aditya. (2013). Panduan Penerapan Siaga Bencana. Jakarta: LIPI 